\title{
Preparation of lactose-free pasteurized milk with a recombinant thermostable $\beta$-glucosidase from Pyrococcus furiosus
}

\author{
Bin $\mathrm{Li}^{1}$, Zemin Wang ${ }^{1}$, Shiwu $\mathrm{Li}^{2}$, William Donelan ${ }^{2}$, Xingli Wang ${ }^{1}$, Taixing Cui ${ }^{3^{*}}$ and Dongqi Tang ${ }^{1 *}$
}

\begin{abstract}
Background: Lactose intolerance is a common health concern causing gastrointestinal symptoms and avoidance of dairy products by afflicted individuals. Since milk is a primary source of calcium and vitamin D, lactose intolerant individuals often obtain insufficient amounts of these nutrients which may lead to adverse health outcomes. Production of lactose-free milk can provide a solution to this problem, although it requires use of lactase from microbial sources and increases potential for contamination. Use of thermostable lactase enzymes can overcome this issue by functioning under pasteurization conditions.

Results: A thermostable $\beta$-glucosidase gene from Pyrococcus furiosus was cloned in frame with the Saccharomyces cerecisiae a-factor secretory signal and expressed in Pichia pastoris strain X-33. The recombinant enzyme was purified by a one-step method of weak anion exchange chromatography. The optimum temperature and pH for this $\beta$-glucosidase activity was $100^{\circ} \mathrm{C}$ and $\mathrm{pH} 6.0$, respectively. The enzyme activity was not significantly inhibited by $\mathrm{Ca}^{2+}$. We tested the additive amount, hydrolysis time, and the influence of glucose on the enzyme during pasteurization and found that the enzyme possessed a high level of lactose hydrolysis in milk that was not obviously influenced by glucose.
\end{abstract}

Conclusions: The thermostablity of this recombinant $\beta$-glucosidase, combined with its neutral pH activity and favorable temperature activity optima, suggest that this enzyme is an ideal candidate for the hydrolysis of lactose in milk, and it would be suitable for application in low-lactose milk production during pasteurization.

Keywords: Recombinant $\beta$-glucosidase, Thermostable enzyme, Pichia pastoris, Milk lactose hydrolysis, Pasteurization

\section{Background}

In vivo, lactase ( $\beta$ - $D$-galactosidase) is an enzyme secreted by intestinal villi that hydrolyses the disaccharide lactose into glucose and galactose $[1,2]$ and is essential for the digestion of bovine milk [3] which contains an average of $4.8 \%$ lactose. Deficiency for this gene [3] leads to malabsorption of lactose and subsequent fermentation of lactose by the gut flora [4]. Lactose intolerance develops when afflicted individuals experience abdominal pain, diarrhea, bloating, flatulence, and other gastrointestinal symptoms

\footnotetext{
* Correspondence: Taixing.Cui@uscmed.sc.edu; tangdq@sdu.edu.cn ${ }^{3}$ Department of Cell Biology and Anatomy, University of South Carolina of Medicine, Columbia, SC 29209, USA

1Shandong University Qilu Hospital Research Center for Cell Therapy, Key Laboratory of Cardiovascular Remodeling and Function Research, Qilu Hospital of Shandong University, Jinan 250012, China

Full list of author information is available at the end of the article
}

following lactose consumption [5]. Avoidance of dairy products by lactose intolerant individuals often leads to insufficient calcium and vitamin D consumption and may cause adverse health outcomes, especially reduced bone mineral density and fractures $[4,6]$.

Since lactose is a disaccharide composed of glucose and galactose, it can be hydrolyzed into these monosaccharides using either a $\beta$-glucosidase or $\beta$-galactosidase. Consumption of lactose-free milk, which can be produced by adding lactase enzyme ( $\beta$-glucosidase or $\beta$-galactosidase) directly to milk, provides a means of maintaining good health while avoiding the symptoms of lactose intolerance. The lactase enzymes most commonly used in the industry are $\beta$-galactosidases, which are generally inhibited as glucose concentration increases. Lactase can be synthesized from many sources including animals, plants, bacteria, fungi, and yeast [7]. Although bacterial sources can

\section{Biomed Central}


efficiently produce lactase, they are not considered safe for use in food production due the risk of microbial contamination [8]. The lactase enzymes most widely used in industry are mesophilic enzymes from fungi (Aspergillus spp.) and yeast (Kluyveromyces spp.) [8]. Fungal sources, with acidic $\mathrm{pH}$-optima, are effective for hydrolyzing lactose in whey, while yeast sources, with neutral pH-optima, are more effective for hydrolyzing lactose in milk [7]. Although pasteurization conditions denature many enzymes, several thermostable lactase enzymes have been identified from a variety of sources [9-12]. Hyperthermophilic archeaeon Pyrococcus furiosus harbors several hydrolytic enzyme activities; notably, it has a thermostable $\beta$-glucosidase (CelB) with a half-life of $85 \mathrm{~h}$ at $100^{\circ} \mathrm{C}$. This enzyme can also function as a $\beta$-galactosidase, but the $\beta$-galactosidase activity is $34.3 \%$ of the $\beta$-glucosidase activity [10]. Although this enzyme has been cloned and functionally characterized in Saccharomyces cerevisiae, expression in batch culture produced low yields $(\sim 10 \mathrm{mg} / \mathrm{L})$ which are not suitable for industrial applications [13]. Still, this $\beta$-glucosidase serves as a model system to use for lactose hydrolysis since it displays extreme stability and high catalytic activity in the presence of lactose.

In the present study, we cloned the $P$. furiosus $\beta$-glucosidase gene (CelB) into the pGAPZaA vector and electrotransformed it into the Pichia pastoris X-33 strain for large-scale production of heterologous proteins by high-density cell culture. The glyceraldehyde-3-phosphate dehydrogenase promoter (pGAP) has been used for large-scale constitutive expression of many heterologous proteins and eliminates problems associated with using the traditional AOX1 promoter such as the hazard and cost associated with the delivery and storage of large volumes of methanol [14-17]. We then analyzed the lactose hydrolytic action of this $\beta$-glucosidase under pasteurization conditions in order to establish a new method for the production of low lactose pasteurized milk. Our system provides a method for high level production of "food grade" thermostable lactase enzyme that is appropriate for use in the milk industry during the process of pasteurization, eliminating the need to add enzyme following pasteurization and eliminating the risk of microbial contamination.

\section{Results}

\section{Fed-batch fermentation}

Unlike the AOX1 promoter which requires methanol to initiate gene expression, the GAP promoter constitutively expresses genes in $P$. pastoris cells grown on many carbon sources [14-17]. Product formation appears to be growth associated in the GAP promoter constitutive expression system, therefore, a higher cell density would help to achieve higher product concentration. The fermentation was a fed-batch process carried out in $5 \mathrm{~L}$ fermenters. The X-33 cells were initially grown on basal salts medium and fed with $50 \%$ glucose after $48 \mathrm{~h}$. Cell concentrations, total protein in supernatant, and enzyme activities during fermentation are shown in Figure 1A. The biomass accumulated at $120 \mathrm{~h}$ was $312 \mathrm{~g} / \mathrm{L}$, enzyme expression reached its peak with a yield of $740 \mathrm{mg} / \mathrm{L}$, and the corresponding $\beta$-glucosidase activity was $271 \mathrm{U} / \mathrm{ml}$. We also tested the $\beta$-galactosidase activity of the enzyme and found it to be $94 \mathrm{U} / \mathrm{ml}$, approximately $35 \%$ of the $\beta$-glucosidase activity. A protein corresponding to recombinant $\beta$-glucosidase, with a molecular mass of approximately $120 \mathrm{kDa}$, was detected upon performing SDS-PAGE analysis with Coomassie Brilliant Blue staining (Figure 1B). This band corresponds to the dimer unit of the enzyme. The native $\beta$-glucosidase is a tetramer, composed of four identical subunits, and each subunit has a molecular mass of $58 \pm 2 \mathrm{kDa}$. The two monomer subunits dimerize by forming a disulfide bond and have a molecular mass of approximately $120 \mathrm{kDa}$. The enzyme dimers form a tetramer through non-covalent bonding, which is the functional native enzyme. It has been previously demonstrated that boiling in SDS is insufficient to denature the dimer which requires additional reagents, such as $\beta$-mercaptoethanol, to cleave the disulfide bonds.

\section{Purification of recombinant $\beta$-glucosidase}

Since the enzyme has a relatively low PI of 4.4 and few secreted proteins are present in the supernatant, we used one-step weak anion exchange chromatography to isolate the target protein, thus making the recombinant production of the enzyme more favorable. Samples of supernatant before and after purification were run side by side using SDS-PAGE (Figure 2B). Figure 2A shows the typical elution profile of chromatography. This procedure resulted in 1.9 fold purification and $80.8 \%$ recovery from the supernatant (Table 1).

\section{Enzyme characterization}

The effects of temperature on enzyme activity and stability are shown in Figure 3A. Optimum temperature was $100^{\circ} \mathrm{C}$, and at $30^{\circ} \mathrm{C}$ the activity decreased to nearly $7 \%$ of the maximum activity. $\beta$-glucosidase was stable and retained more than $80 \%$ of its maximum activity from $30^{\circ} \mathrm{C}$ to $120^{\circ} \mathrm{C}$. Regarding $\mathrm{pH}, \beta$-glucosidase presented optimum activity at pH 6.0 (Figure 3B) and was nearly inactivated at extreme $\mathrm{pH}(\mathrm{pH} 4.0$ and 9.0). $\beta$-glucosidase retained more than $80 \%$ of its maximum activity from $\mathrm{pH} 5.0$ to 8.0 when pre-incubated at $37^{\circ} \mathrm{C}$ for 1 hour. The effect of metal cations on the $\beta$-glucosidase activity is shown in Table 2 , and although $\mathrm{Cu}^{2+}$ can reduce the relative activity to $78 \%$, other metal cations have only negligible effects on the activity of the recombinant enzymes. Importantly, $\mathrm{Ca}^{2+}$ did not significantly inhibit the activity of the enzyme. 

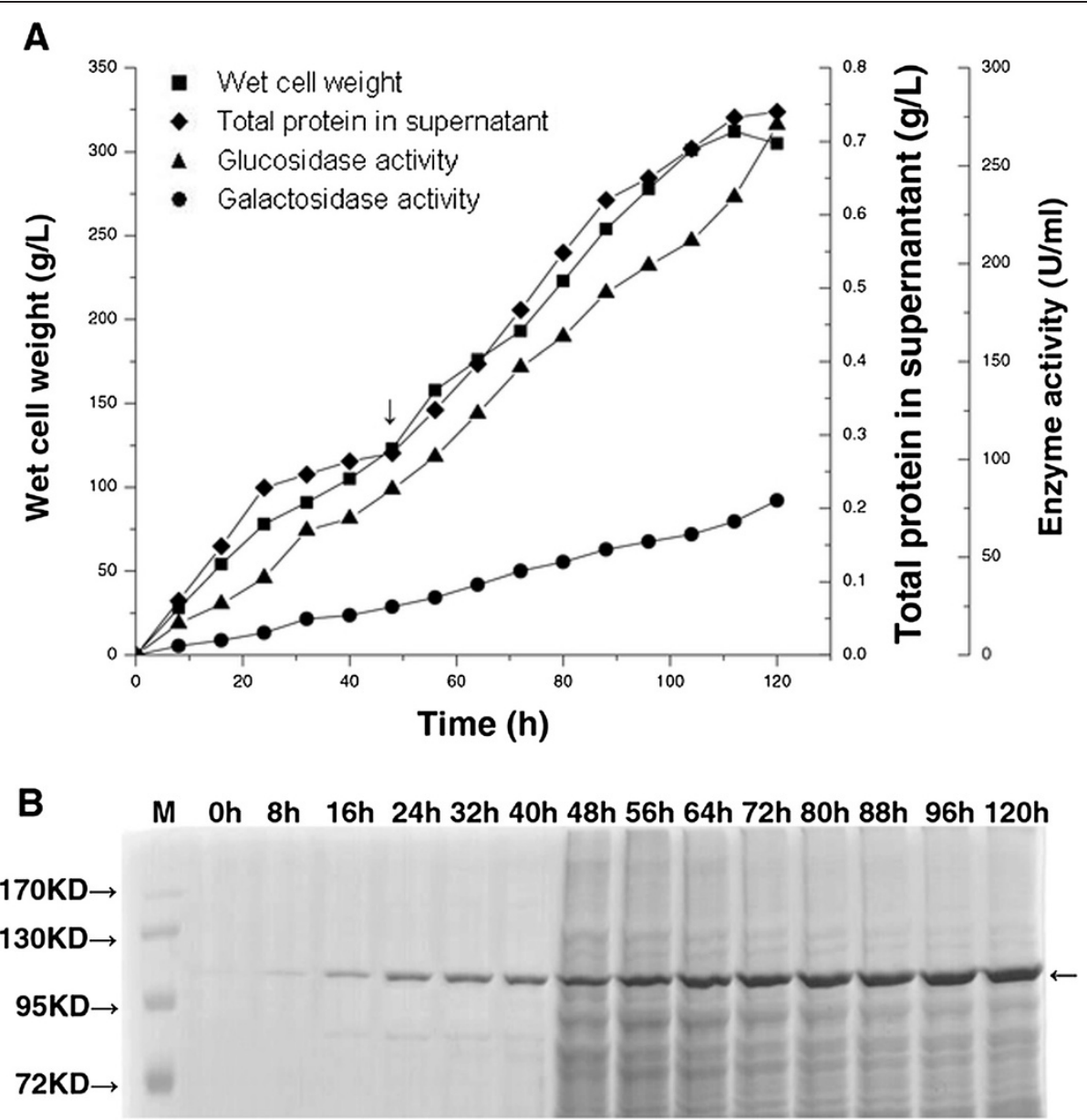

Figure 1 Time course of recombinant enzyme properties and protein analysis during fermentation. A. Wet cell weight (square), total protein in supernatant (diamond), $\beta$-glucosidase activity (triangle), and $\beta$-galactosidase activity (circle) were assessed as a function of time for $120 \mathrm{~h}$ fermentation in a $5 \mathrm{~L}$ fermenter. The arrow shows the time point for addition of glucose. B. Total protein in culture supernatant was assessed by Coomassie Brilliant Blue R-250 staining following SDS-PAGE (10\%) during high cell density fermentation in a $5 \mathrm{~L}$ fermenter. Arrow at approximately $120 \mathrm{kDa}$ shows the recombinant $\beta$-glucosidase. Each lane shows culture supernatant at indicated time and $\mathrm{M}=$ protein size marker.

\section{Hydrolysis of lactose in milk under pasteurization conditions}

The ability of $\beta$-glucosidase to hydrolyze the lactose in milk at $65^{\circ} \mathrm{C}$ for $30 \mathrm{~min}$ was tested using different amounts of the recombinant enzyme (Figure 4A) and then analyzed by HPLC (Figure 4B) which showed that the lactose in milk can be hydrolyzed into glucose and galactose. Using $17 \mathrm{U} / \mathrm{ml}$ of recombinant $\beta$-glucosidase achieved $50 \%$ hydrolysis and increasing to $498 \mathrm{U} / \mathrm{ml}$ of recombinant enzyme resulted in greater than $90 \%$ hydrolysis. We also tested the efficiency of hydrolysis of this enzyme (311 U/ml) from 5-30 minutes (Figure 5A-B) and found that after 20 minutes, the amount of hydrolysis was similar to 30 minutes. Therefore, we have demonstrated that the enzyme activity was more than sufficient to remove lactose in milk under pasteurization conditions. The effects of glucose concentration on hydrolysis was also tested, and we found that even high concentrations of glucose $(5 \%)$ had minimal influence on the hydrolysis of lactose (Figure 6A-B), demonstrating that the enzyme had a relatively good tolerance to glucose. These results show that this recombinant thermostable $\beta$-glucosidase is highly-effective at hydrolyzing lactose in milk under pasteurization conditions.

\section{Discussion}

Voorhorst [18] reported using E. coli to express the $\beta$ glucosidase gene. The expressed product remained within the host cell and necessitates complicated purification methodologies. Moreover, E. coli is not considered safe for food applications. Smith [13] reported expressing the $\beta$-glucosidase gene in $S$. cerevisiae, but the yield is very low at only $10 \mathrm{mg} / \mathrm{L}$ in batch culture. The development of the $S$. cerevisiae expression system was limited by the lack of a strong promoter and being incapable of highdensity cell culture. Recently, $P$. pastoris has been widely 
A

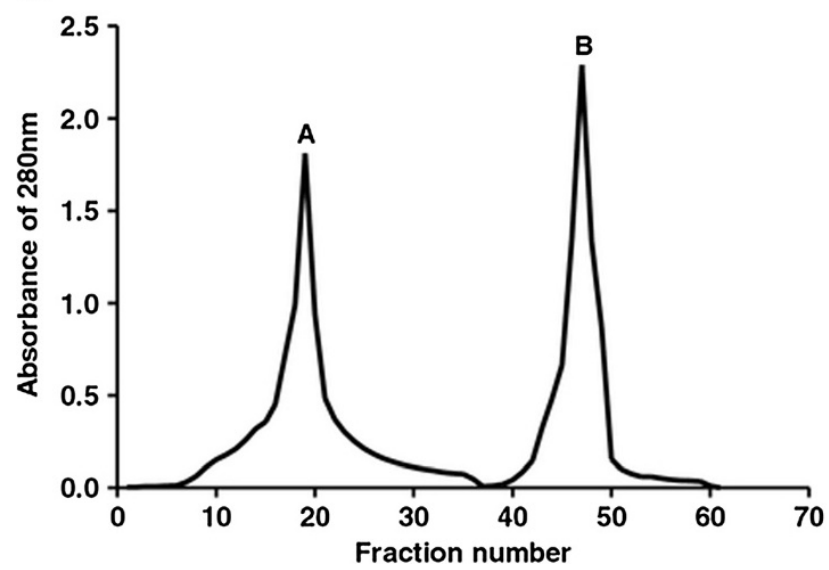

B

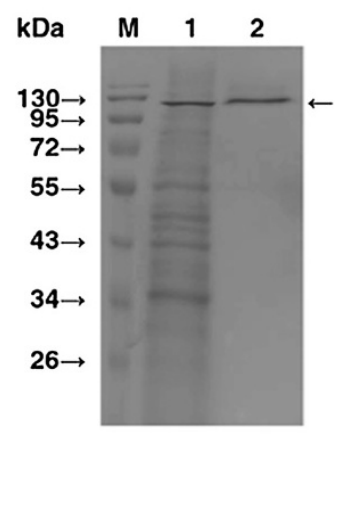

Figure 2 DEAE anion exchange chromatography and SDS-PAGE analysis of the recombinant $\beta$-glucosidase. A. Anion exchange chromatography was used to measure protein by its absorbance at $280 \mathrm{~nm}$ with increasing fractions as indicated on the x-axis. Two successive $\mathrm{NaCl}$ concentrations were used first to first elute non-specific protein and then to elute the recombinant $\beta$-glucosidase. Peak A demonstrates other impurity proteins eluted with $200 \mathrm{mM} \mathrm{NaCl}$ and peak B is recombinant $\beta$-glucosidase eluted with $400 \mathrm{mM} \mathrm{NaCl}$. B. Following secretion, supernatant was collected and SDS-PAGE was performed before and after purification. Lane M shows a protein size marker, lane 1 shows total protein in culture supernatant before purification, and lane 2 shows recombinant $\beta$-glucosidase following purification. The arrow at approximately $120 \mathrm{kDa}$ shows the $\beta$-glucosidase dimer.

used as an efficient expression system, secreting very low levels of its own proteins. The secreted heterologous protein is often virtually the only one protein in the culture medium. Thus, we cloned and expressed the $\beta$-glucosidase gene from $P$. furiosus into $P$. pastoris, and to our knowledge, this is the first use of $P$. pastoris to express this enzyme.

In the past, many researchers chose the methanol oxidase (AOX1) promoter to construct expression vectors for the production of a variety of recombinant proteins in $P$. pastoris [19-23]. It is especially effective for gene expression of products that are toxic to the host. However, methanol is a toxic substance, causes environment pollution, and is a fire hazard during production. Additionally, it is inconvenient to change from glucose or glycerol to methanol during fermentation. Therefore, we chose the constitutive GAP promoter for the production of this recombinant enzyme. This system is more desirable for large scale production because the hazard and cost associated with the storage and delivery of large volumes of methanol are eliminated.

The recombinant enzyme was cultivated in a $5 \mathrm{~L}$ fermentor, and after $120 \mathrm{~h}$, we obtained $740 \mathrm{mg} / \mathrm{L}$ of $\beta$-glucosidase. Even when expression was not fully optimized, we achieved 700-fold higher levels than with E.coli expression and 70-fold greater than the $S$. cerevisiae system $[13,18]$. In another $300 \mathrm{~L}$ fermentor, we obtained $7 \mathrm{~g} / \mathrm{L}$ of recombinant $\beta$-glucosidase after $160 \mathrm{~h}$, which is quite convenient to use for industrial production.
The $\mathrm{pH}$ optimum of recombinant enzyme lies slightly above the $\beta$-glucosidase from $P$. furiosus ( $\mathrm{pH}$ 5.0) and the temperature optimum $\left(100^{\circ} \mathrm{C}\right)$ of the enzyme was similar with the $\beta$-glucosidase of $P$. furiosus $\left(102-105^{\circ} \mathrm{C}\right)$. The purified enzymes showed a remarkable thermostability, and even incubation at $100^{\circ} \mathrm{C}$ for 1 hour didn't change the activity significantly. The enzyme was not significantly stimulated or inhibited by divalent cations, as found for some glycosidases.

The ability of the recombinant $\beta$-glucosidase to hydrolyze lactose in milk under pasteurization conditions was tested and analyzed by HPLC. The lactose in the milk can be easily hydrolyzed into glucose and galactose. The maximum amount of hydrolysis was $91 \%$ when using $498 \mathrm{U} / \mathrm{ml}$ of the recombinant $\beta$-glucosidase at $65^{\circ} \mathrm{C}$ for $30 \mathrm{~min}$. This is quite useful for industrial production of low lactose milk and milk powder under pasteurization conditions and the established industrial systems (which are much more efficient than those in our research laboratory) would likely require less enzyme to achieve similar results. In the past, the lactases

Table 1 Summary of the thermostable $\beta$-glucosidase purification from recombinant Pichia pastoris

\begin{tabular}{llllll}
\hline Step & $\begin{array}{l}\text { Total } \\
\text { protein } \\
(\mathbf{m g})\end{array}$ & $\begin{array}{l}\text { Total } \\
\text { activity } \\
(\mathbf{U})\end{array}$ & $\begin{array}{l}\text { Specific } \\
\text { activity } \\
\mathbf{( U / m g )}\end{array}$ & $\begin{array}{l}\text { Yield } \\
\mathbf{( \% )}\end{array}$ & $\begin{array}{l}\text { Purification } \\
\text { (fold) }\end{array}$ \\
\hline Cell-free extract & 25.3 & 9362.3 & 366.1 & 100 & 1 \\
$\begin{array}{l}\text { DEAE anion } \\
\text { exchange }\end{array}$ & 10.9 & 7571.1 & 694.6 & 80.8 & 1.9 \\
\hline
\end{tabular}




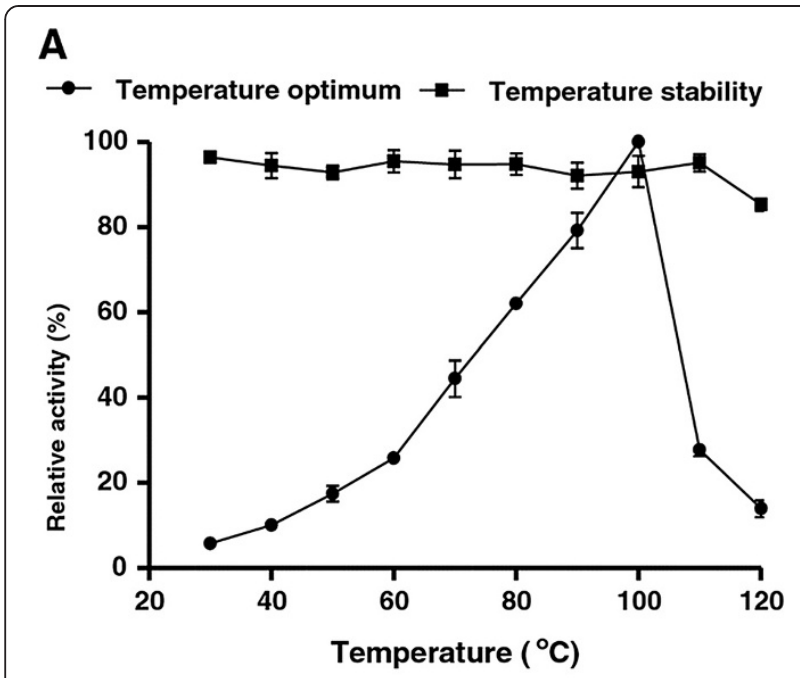

B $\rightarrow$ pH optimum $\rightarrow$ pH stability

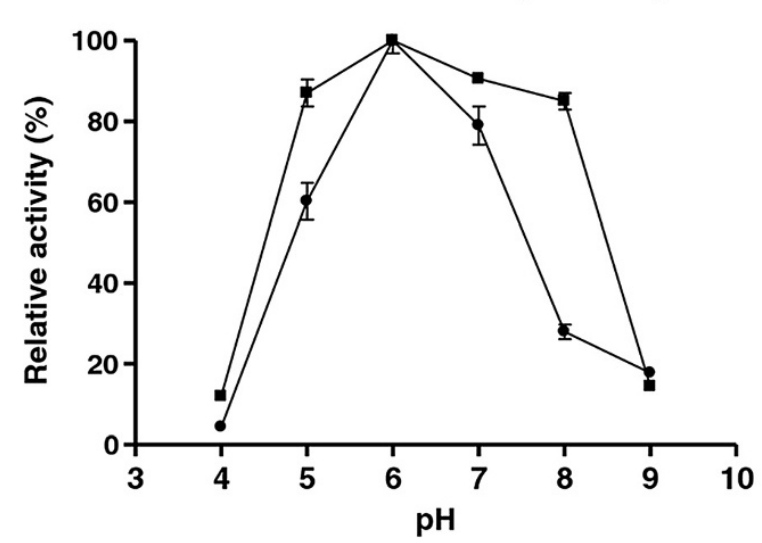

Figure 3 Effects of temperature and $\mathrm{pH}$ on the recombinant $\beta$-glucosidase activity and stability. A. $\beta$-glucosidase activities, as measured by temperature optimum (circle) or temperature stability (square) are shown as a function of temperature ranging from $30^{\circ} \mathrm{C}-120^{\circ} \mathrm{C}$. All data are presented as the mean \pm SD of triplicate determinations. B. $\beta$-glucosidase activities, as measured by $\mathrm{pH}$ optimum (circle) or $\mathrm{pH}$ stability (square) are shown as a function of $\mathrm{pH}$ ranging from $\mathrm{pH} 4-\mathrm{pH}$. All data are presented as the mean \pm SD of triplicate determinations.

most widely used in industry were obtained from Aspergillus spp. and Kluyveromyces spp, but they are all mesophilic enzymes, which cannot be used before pasteurization, and adding the enzymes after pasteurization leads to a high risk of contamination. Moreover, the hydrolysis time of these enzymes is generally more than 24 hours $[24,25]$, which is too long for the production of pasteurized milk. However, these problems are all solved by using the recombinant thermotolerant $\beta$-glucosidase. Using this enzyme before pasteurization decreases the risk of bacterial contamination, and incubating at $65^{\circ} \mathrm{C}$ for 30 min can effectively hydrolyze more than $90 \%$ of milk lactose. In addition, we found the hydrolysis
Table 2 Effects of metal ions on the activity of the recombinant $\beta$-glucosidase

\begin{tabular}{ll}
\hline Metal ions & Relative activity \pm SD (\%) \\
\hline Control & $100 \pm 2.67$ \\
$\mathrm{Mn}^{2+}$ & $99.48 \pm 3.54$ \\
$\mathrm{Cu}^{2+}$ & $77.67 \pm 2.71$ \\
$\mathrm{Na}^{+}$ & $105.43 \pm 3.89$ \\
$\mathrm{Mg}^{2+}$ & $102.26 \pm 6.95$ \\
$\mathrm{~K}^{+}$ & $100.95 \pm 4.84$ \\
$\mathrm{Ca}^{2+}$ & $95 \pm 4.76$ \\
$\mathrm{Zn}^{2+}$ & $98.67 \pm 3.72$ \\
\hline
\end{tabular}

Effects of metal ions $(1 \mathrm{mM})$ on the activity of the recombinant $\beta$-glucosidase are shown. Data are presented as the means \pm SD of triplicate determinations.

efficiency of the enzyme at $65^{\circ} \mathrm{C}$ for 20 minutes was similar to $65^{\circ} \mathrm{C}$ for 30 minutes. Different from many other glucosidases [26-30], glucose has relatively small influence on this enzyme. We added $5 \%$ glucose to the milk and found that the lactose hydrolysis efficiency only decreased slightly, highlighting another advantage of using this enzyme in low lactose milk production. In conclusion, the enhanced stability of this recombinant thermostable $\beta$-glucosidase, combined with its neutral $\mathrm{pH}$ activity and favorable temperature activity optima, suggest that this enzyme is an ideal candidate for the hydrolysis of lactose in milk and would be suitable for application in low-lactose milk production during milk pasteurization.

\section{Conclusions}

This report is the first on the cloning, expression, purification, and characterization of the $\beta$-glucosidase from $P$. furiosus in $P$. pastoris. We achieved an enzyme yield of up to $740 \mathrm{mg} / \mathrm{L}$ using basal salts medium and purified the enzyme in one step anion exchange chromatography to near electrophoretic homogeneity. In this study, we established a new method to produce low lactose milk using this enzyme under pasteurization conditions. This method highlights the potential for low lactose milk production without additional steps required to add enzymes following pasteurization, and thus, decreases the risk of microbial contamination to a great extent.

\section{Methods}

\section{Cloning and gene expression}

The genomic DNA from P. furiosus DSMZ 3638 (ATCC), $P$. pastoris $\mathrm{X}-33$, and $\mathrm{pGAPZaA}$ vector (Invitrogen) were used as the sources of the $\beta$-glucosidase gene (CelB), host cells, and expression vector, respectively. The gene encoding the $\beta$-glucosidase (CelB) was amplified by polymerase chain reaction $(\mathrm{PCR})$ using the genomic DNA isolated from $P$. furiosus as a template. The sequence of the 


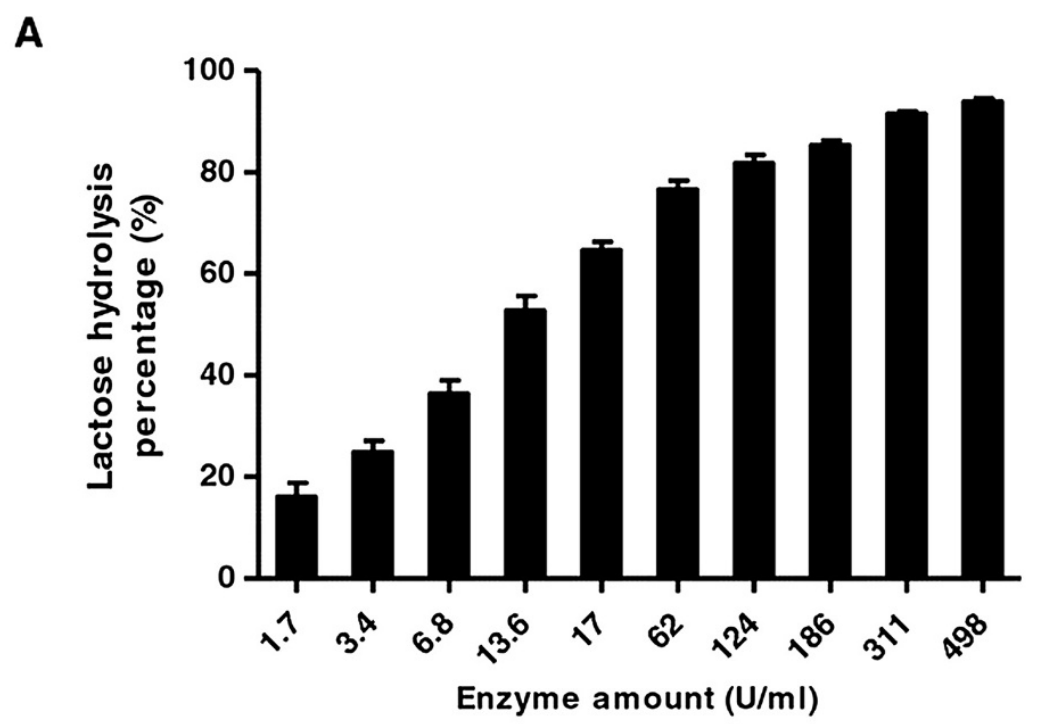

B

(1)

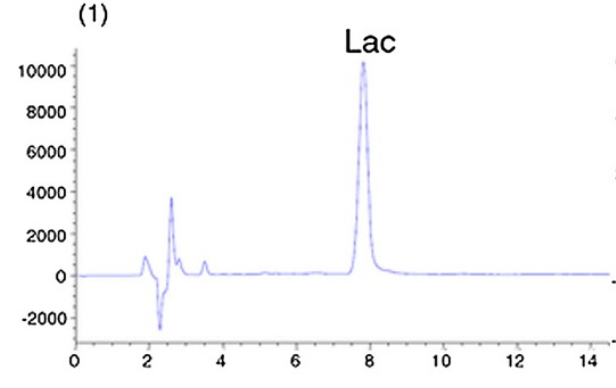

(3)

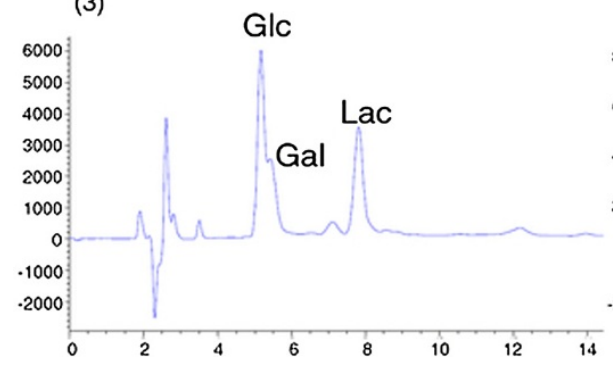

(2)

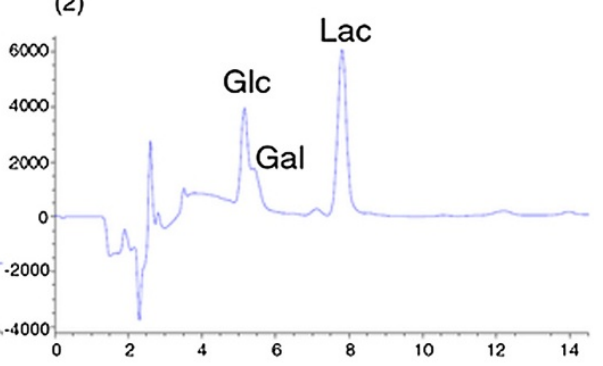

(4)

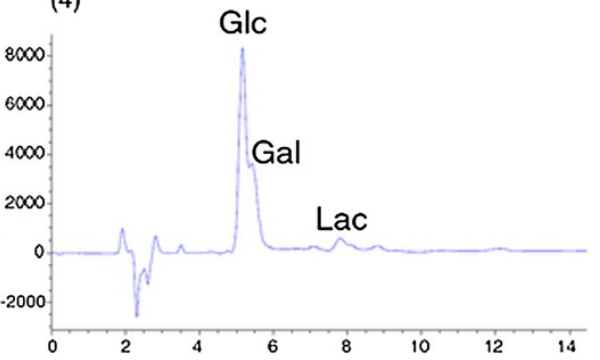

Figure 4 Efficiency of $\beta$-glucosidase amount on lactose hydrolysis in milk and analyzed by HPLC. A. Lactose hydrolysis was measured as a function of enzyme quantity $(\mathrm{U} / \mathrm{ml})$ at $65^{\circ} \mathrm{C}$ for 30 min using different concentrations of enzyme ranging from $1.7 \mathrm{U} / \mathrm{ml}$ to $498 \mathrm{U} / \mathrm{ml}$ as indicated. All data are presented as the mean $\pm \mathrm{SD}$ of triplicate determinations. B. HPLC analysis of the reactions performed at $65^{\circ} \mathrm{C}$ for $30 \mathrm{~min}$ with $0 \mathrm{U} / \mathrm{ml}$ (Panel 1), $17 \mathrm{U} / \mathrm{ml}$ (Panel 2), $186 \mathrm{U} / \mathrm{ml}$ (Panel 3), or $498 \mathrm{U} / \mathrm{ml}$ (Panel 4) $\beta$-glucosidase enzyme. Lac = lactose, Glc = glucose, Gal = galactose.

oligonucleotide primers used for gene cloning was based on the DNA sequence of $P$. furiosus $\beta$-glycosidase [Genbank accession number No. AF013169]. Forward primer [5'-GAATTCATGAAGTTCTCCAAAAAAC-3'] and reverse primers [5'-TCTAGACTTTCTTGTAACAAATT-3'] were designed to introduce the EcoRI and XbaI restriction sites (underlined), respectively, and were synthesized by Invitrogen. The amplified DNA fragment obtained by PCR was purified and inserted into the pGAPZaA vector digested with the same restriction enzymes. Pichia pastoris X-33 strain was transformed with the ligation mixture using an electroporator and plated on YPD agar containing $800 \mathrm{ug} / \mathrm{ml}$ of Zeocin (Invitrogen). A Zeocinresistant colony was selected. Gene expression was evaluated by both sodium dodecyl sulfate polyacrylamide gel electrophoresis (SDS-PAGE) and enzyme activity.

\section{Fed-batch fermentation}

Fermentation studies were conducted in $5 \mathrm{~L}$ fermenters (Baoxing Co, Shanghai, China). Inoculum was cultured 


\section{A}

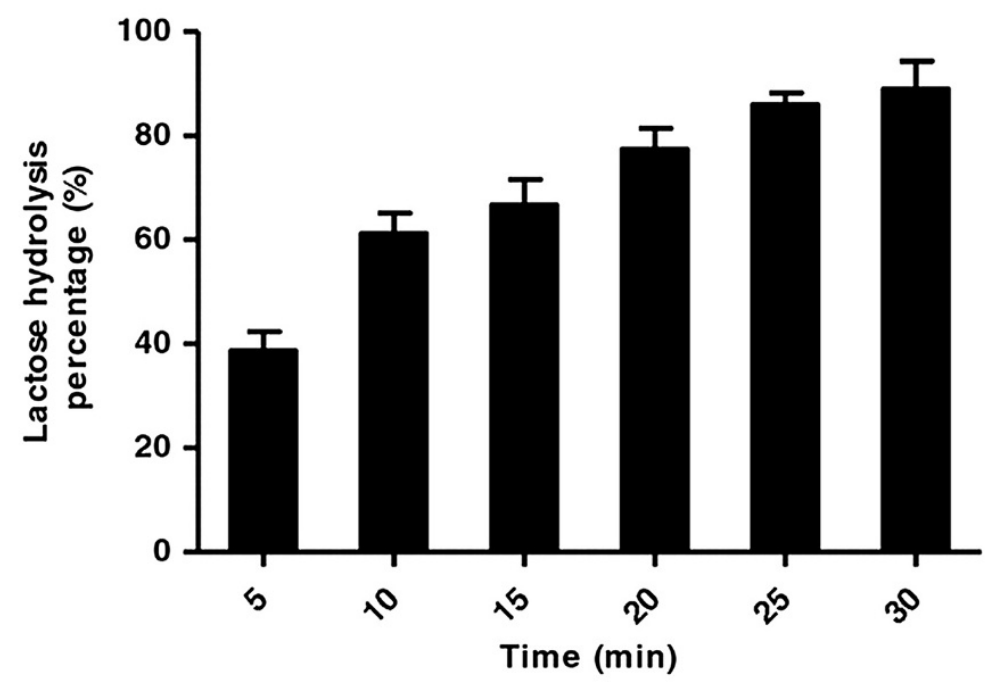

B

(1)

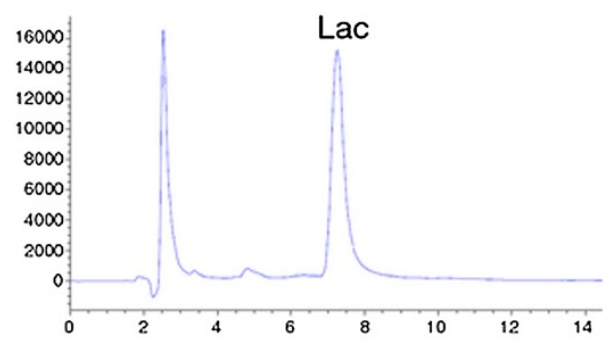

(3)

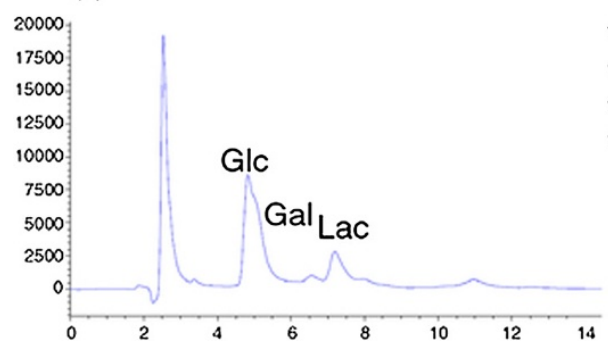

(2)

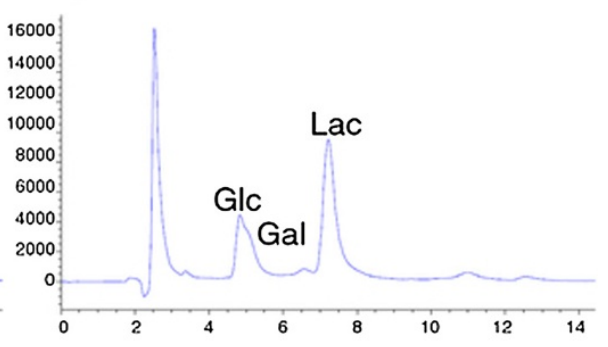

(4)

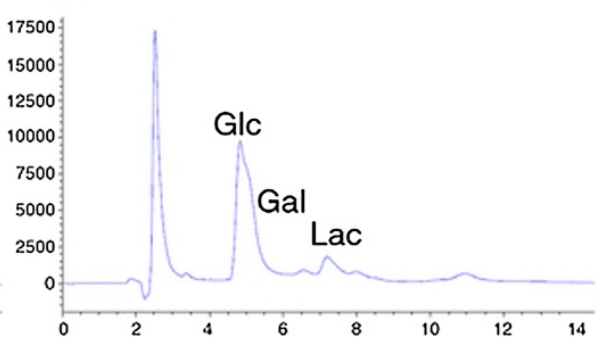

Figure 5 Time course for efficiency of $\beta$-glucosidase on lactose in milk and analyzed by HPLC. A. Lactose hydrolysis was measured as a function of time using $311 \mathrm{U} / \mathrm{ml} \beta$-glucosidase enzyme at $65^{\circ} \mathrm{C}$ ranging from $5 \mathrm{~min}$ to $30 \mathrm{~min}$. All data are presented as the mean $\pm \mathrm{SD}$ of triplicate determinations. B. HPLC analysis of the reactions performed at $65^{\circ} \mathrm{C}$ using $311 \mathrm{U} / \mathrm{ml} \beta$-glucosidase enzyme for 0 min (Panel 1), 10 min (Panel 2), $20 \mathrm{~min}$ (Panel 3), or $30 \mathrm{~min}$ (Panel 4). Lac = lactose, Glc = glucose, Gal = galactose.

in yeast extract peptone dextrose (YPD) medium. Cells were grown for $18 \mathrm{~h}$ at $30^{\circ} \mathrm{C}$ on a shaker at $220 \mathrm{rpm}$. Then, $10 \%(\mathrm{v} / \mathrm{v})$ of the inoculum was inoculated into the $5 \mathrm{~L}$ fermenters containing $2 \mathrm{~L}$ basal salts medium. Basal salts medium used for fermenter batch cultivation contained (per liter deionized water): glycerol $40 \mathrm{~g}$, $\mathrm{H}_{3} \mathrm{PO}_{4}$ (85\%) $26.7 \mathrm{ml}, \mathrm{K}_{2} \mathrm{SO}_{4} 18.2 \mathrm{~g}, \mathrm{MgSO}_{4} .7 \mathrm{H}_{2} \mathrm{O} 14.9 \mathrm{~g}$, $\mathrm{KOH} 4.13 \mathrm{~g}, \mathrm{CaSO}_{4} 0.93 \mathrm{~g}$, trace salts solution $4.35 \mathrm{ml}$ (trace salts solution [per liter deionized water]: $\mathrm{Fe}_{2} \mathrm{SO}_{4} .7 \mathrm{H}_{2} \mathrm{O} 65 \mathrm{~g}, \mathrm{ZnCl}_{2} 20 \mathrm{~g}, \mathrm{CuSO}_{4} .5 \mathrm{H}_{2} \mathrm{O} 6 \mathrm{~g}, \mathrm{MnSO}_{4}$.
$\mathrm{H}_{2} \mathrm{O} 3 \mathrm{~g}, \mathrm{CoCl}_{2} 0.5 \mathrm{~g}, \mathrm{Na}_{2} \mathrm{MoO}_{4} .2 \mathrm{H}_{2} \mathrm{O} 0.2 \mathrm{~g}, \mathrm{NaI} 0.08$ g, $\mathrm{H}_{3} \mathrm{BO}_{3} 0.02 \mathrm{~g}$, Biotin $0.2 \mathrm{~g}$, and $\mathrm{H}_{2} \mathrm{SO}_{4} 5.0 \mathrm{ml}$ ). The temperature was maintained at $30^{\circ} \mathrm{C}$ and the dissolved oxygen (DO) level was maintained between $25 \%$ and $35 \%$ by adjusting the agitation and aerating rate. The $\mathrm{pH}$ was kept at 6.0 by the addition of $28 \%$ (w/w) ammonium hydroxide. Foaming was controlled through the addition of antifoam. The glucose fed-batch feeding was started at the end of a batch phase triggered by the increase of DO above a set point of $50 \%$. The composition 
A

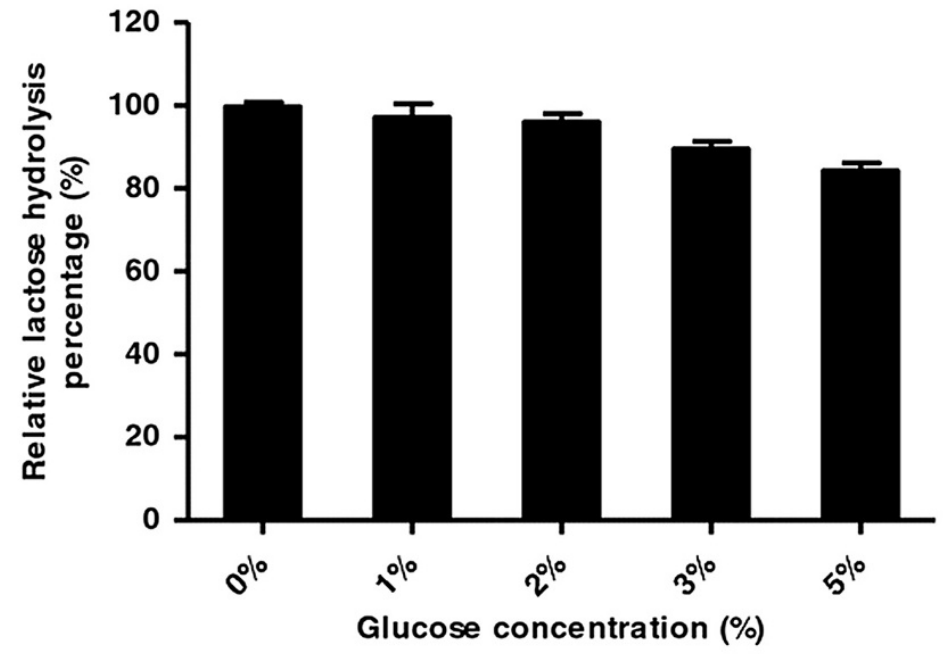

B

(1)

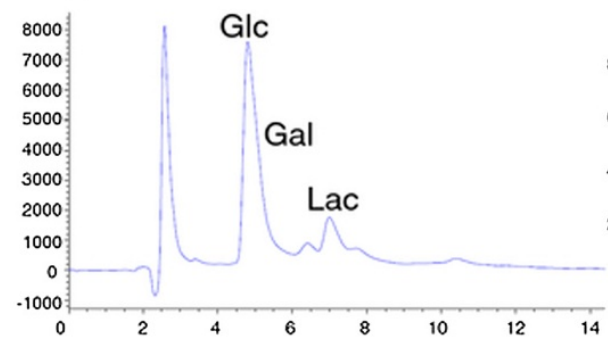

(2)

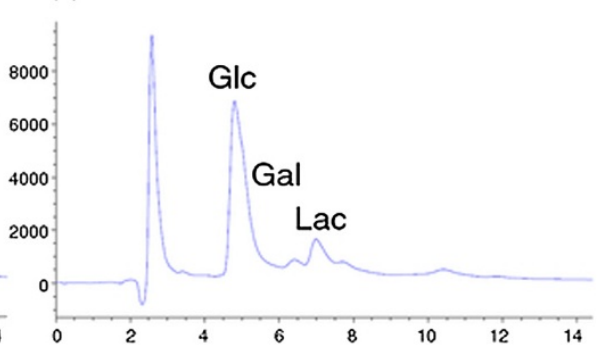

(4)

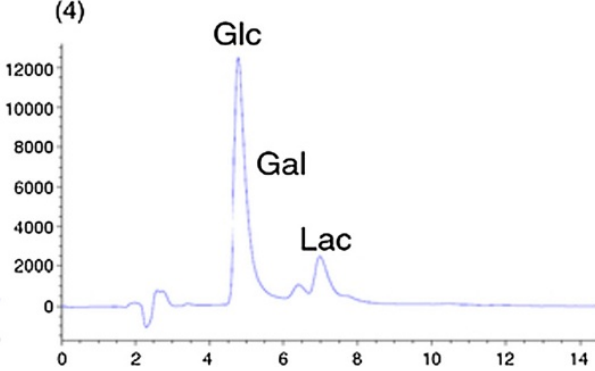

Figure 6 Efficiency of $\beta$-glucosidase on lactose hydrolysis in milk with glucose. A. Lactose hydrolysis was measured at $65^{\circ} \mathrm{C}$ for 30 min using $311 \mathrm{U} / \mathrm{ml} \beta$-glucosidase enzyme with increasing concentrations of glucose ranging from $0-5 \%$ as indicated. All data are presented as the mean \pm SD of triplicate determinations. B. HPLC analysis of the reactions performed at $65^{\circ} \mathrm{C}$ for $30 \mathrm{~min}$ using $311 \mathrm{U} / \mathrm{ml} \beta$-glucosidase enzyme with the addition of 0\% glucose (Panel 1), $1 \%$ glucose (Panel 2), $2 \%$ glucose (Panel 3), or $5 \%$ glucose (Panel 4). Lac = lactose, Glc = glucose, Gal = galactose.

of the fed-batch feeding medium was as follows (per liter deionized water): glucose $500 \mathrm{~g} / \mathrm{L}$ and $1 \mathrm{ml} \mathrm{PTM} 4$ trace salts solution. Samples were taken at regular intervals and analyzed for biomass, total protein in medium, and enzyme activity.

\section{SDS-PAGE analysis}

SDS-PAGE was performed using a $10 \%$ polyacrylamide gel on a vertical mini gel apparatus (Bio-Rad) at $120 \mathrm{~V}$ for $2 \mathrm{~h}$. Protein molecular weight marker was purchased from Fermentas Life Science. Proteins were stained with Coomassie Brilliant Blue R-250.

\section{Purification of $\beta$-glucosidase}

The yeast cells were removed by centrifugation at $8000 \mathrm{rpm}$ for $10 \mathrm{~min}$. The supernatant was filtered and loaded on diethylaminoethyl cellulose (DEAE)-sepharose weak anion exchange column $(2.5 \times 30 \mathrm{~cm})$ equilibrated with $20 \mathrm{mM}$ Tris- $\mathrm{HCl}$ buffer, $\mathrm{pH}$ 8.0. After washing with wash buffer $(20 \mathrm{mM}$ Tris- $\mathrm{HCl}, 200 \mathrm{mM} \mathrm{NaCl})$, the 
$\beta$-glucosidase was eluted with $400 \mathrm{mM} \mathrm{NaCl}$ in the same buffer at a flow rate of $1 \mathrm{ml} / \mathrm{min}$.

\section{Enzyme assay of the recombinant $\beta$-glucosidase}

The colorimetric assay used to determine enzyme activity was modified from previously described protocols [25,28-30]. As a standard assay procedure, a standard curve was made using p-nitrophenol (pNP) in concentrations of $1 \mathrm{mM}$, and the absorbance was measured at $405 \mathrm{~nm}$. Then, the $\beta$-glucosidase activity was measured at $85^{\circ} \mathrm{C}$ with $10 \mathrm{mM}$ p-nitrophenol- $\beta$-D-glucopyranoside (pNPG, Sigma) as a substrate in $50 \mathrm{mM}$ sodium citrate buffer (pH6.0). After $15 \mathrm{~min}$ of incubation, the reaction was stopped by adding $5 \%(\mathrm{w} / \mathrm{v}) \mathrm{Na}_{2} \mathrm{CO}_{3}$ and the release of pNP was measured at $405 \mathrm{~nm}$. The results were calculated by using the equation obtained in the standard curve. In all analyses, one unit (U) was defined as the amount of enzyme that releases 1 umol of pNP per minute. The $\beta$-galactosidase activity of the recombinant enzyme was measured at the same time using substrate ONP and ONPG with the same method.

\section{Effect of temperature on $\beta$-glucosidase activity and stability}

In order to determine the optimum temperature of $\beta$-glucosidase, an appropriate concentration of the enzyme was incubated with $10 \mathrm{mM}$ pNPG in $50 \mathrm{mM}$ sodium citrate buffer ( $\mathrm{pH}$ 6.0) for $15 \mathrm{~min}$ at different temperatures ranging from 30 to $120^{\circ} \mathrm{C}$, and the activity was measured as the standard assay method. To determine the thermostability of $\beta$-glucosidase, the purified enzyme was pre-incubated at different temperatures ranging from $30^{\circ} \mathrm{C}$ to $120^{\circ} \mathrm{C}$ in $50 \mathrm{mM}$ sodium citrate buffer (pH 6.0) without substrate. After incubating for $1 \mathrm{~h}$, the residual $\beta$-glucosidase activity was measured according to the standard assay procedure using pNPG as the substrate and the maximum activity obtained was taken to be $100 \%$. Data are presented as the means \pm SD of triplicate determinations.

\section{Effect of $\mathrm{pH}$ on $\beta$-glucosidase activity and stability}

The optimum $\mathrm{pH}$ value of $\beta$-glucosidase was determined by incubating the purified enzyme at $100^{\circ} \mathrm{C}$ for $15 \mathrm{~min}$ in different buffers in the range of 4.0-9.0. To determine the $\mathrm{pH}$ stability of $\beta$-glucosidase, the purified enzyme was incubated in different buffers in the range of 4.0-9.0 without substrate at $37^{\circ} \mathrm{C}$ for $1 \mathrm{~h}$. The buffers used in this experiment were $50 \mathrm{mM}$ sodium citrate, $50 \mathrm{mM}$ sodium phosphate, and $50 \mathrm{mM}$ glycine- $\mathrm{NaOH}$. The remaining activities were measured according to the standard assay procedure using PNPG as the substrate and the maximum activity obtained was taken to be $100 \%$. Data are presented as the means \pm SD of triplicate determinations.

\section{Effect of metal ions on $\beta$-glucosidase activity}

The effects of various metal ions $\left(1 \mathrm{mM}\right.$ each of $\mathrm{MnCl}_{2}$, $\mathrm{CuCl}_{2}, \mathrm{NaCl}, \mathrm{MgCl}_{2}, \mathrm{KCl}, \mathrm{CaCl}_{2}$, and $\mathrm{ZnCl}_{2}$ ) on $\beta$ glucosidase activity were studied. The enzymes were individually pre-incubated with reagents at $37^{\circ} \mathrm{C}$ for $1 \mathrm{~h}$. The remaining activities were measured as the standard assay procedures using pNPG as the substrate, and the control enzyme activity without cations was taken as $100 \%$. Data are presented as the means \pm SD of triplicate determinations.

\section{Hydrolysis of lactose in milk at the condition of pasteurization}

The ability of $\beta$-glucosidase to catalyze lactose in milk at pasteurization condition was tested. $100 \mathrm{ml}$ of raw milk was incubated with different amounts enzyme at $65^{\circ} \mathrm{C}$ for $30 \mathrm{~min}$ in a shaker at $120 \mathrm{rpm}$. Aliquots of $10 \mathrm{~mL}$ were removed at each time point (in time course study), transferred to $15-\mathrm{mL}$ test tubes with screw-on caps, and immediately frozen at $-80^{\circ} \mathrm{C}$ to stop the hydrolysis reaction. Lactose content was determined by HPLC. HighPerformance Liquid Chromatography (HPLC) analysis of lactose hydrolysis was performed using an HPLC system with a quaternary pump, automatic injector, and differential refractive index detector (Agilent). The separation was carried out on a ZORBAX Eclipse XDB- $\mathrm{NH}_{2}$ column (5 um, $250 \mathrm{~mm} \times 4.6 \mathrm{~mm}$ i.d.). The mobile phase was A ( $75 \%$ acetonitrile) and B ( $25 \%$ water). The flow rate was $1.4 \mathrm{ml} / \mathrm{min}$, with an injection volume of $20 \mathrm{ul}$.

\section{Abbreviations}

P. furiosus: Pyrococcus furiosus; E. coli: Escherichia coli;

S. cerevisiae: Saccharomyces cerevisiae; PCR: Polymerase chain reaction; SDS-PAGE: Sodium dodecyl sulfate polyacrylamide gel electrophoresis; YPD: Yeast extract peptone dextrose; DO: Dissolved oxygen;

DEAE: Diethylaminoethyl cellulose; pNP: p-nitrophenol; pNPG: p-nitrophenol$\beta$-D-glucopyranoside; HPLC: High-Performance Liquid Chromatography.

\section{Competing interest}

The authors declare that they have no competing interest.

\section{Authors' contributions}

BL carried out the fermentation, purification, enzyme characterization of the recombinant enzyme. ZMW participated in fermentation, purification and

hydrolysis of lactose in milk. SWL participated in the cloning and expression of the $\beta$-glucosidase in Pichia pastoris. WD assisted with experimental

analysis and manuscript editing. XLW and TXC contributed the study design and critical revision of the manuscript. DQT directed the cultivation of experiments and prepared the final manuscript. All authors read and approved the final manuscript.

\section{Acknowledgements}

This work was supported by grants from the organization of the recruitment program of global experts (Xing-Li Wang) from the University of Shandong.

\section{Author details}

${ }^{1}$ Shandong University Qilu Hospital Research Center for Cell Therapy, Key Laboratory of Cardiovascular Remodeling and Function Research, Qilu Hospital of Shandong University, Jinan 250012, China. ${ }^{2}$ Department of Pathology, Immunology, and Laboratory Medicine, University of Florida College of Medicine, Gainesville, FL 32610, USA. ${ }^{3}$ Department of Cell Biology 
and Anatomy, University of South Carolina of Medicine, Columbia, SC 29209, USA.

Received: 5 April 2013 Accepted: 16 September 2013

Published: 21 September 2013

\section{References}

1. Mantei N, Villa M, Enzler T, Wacker H, Boll W, James P, Hunziker W, Semenza $\mathrm{G}$ : Complete primary structure of human and rabbit lactase-phlorizin hydrolase: implications for biosynthesis, membrane anchoring and evolution of the enzyme. EMBO J 1988, 7(9):2705-2713.

2. Skovbjerg $H$, Sjostrom $H$, Noren O: Purification and characterisation of amphiphilic lactase/phlorizin hydrolase from human small intestine. Eur J Biochem 1981, 114(3):653-661.

3. Swallow DM: Genetics of lactase persistence and lactose intolerance. Annu Rev Genet 2003, 37:197-219.

4. Suchy FJ, Brannon PM, Carpenter TO, Fernandez JR, Gilsanz V, Gould JB, Hall K, Hui SL, Lupton J, Mennella J, et al: NIH consensus development conference statement: Lactose intolerance and health. NIH Consens State Sci Statements 2010, 27(2):1-27.

5. Vesa TH, Marteau P, Korpela R: Lactose intolerance. J Am Coll Nutr 2000, 19(2 Suppl):165S-175S

6. Enattah NS, Sulkava R, Halonen P, Kontula K, Jarvela I: Genetic variant of lactase-persistent $\mathrm{C} / \mathrm{T}-13910$ is associated with bone fractures in very old age. J Am Geriatr Soc 2005, 53(1):79-82.

7. Husain Q: Beta galactosidases and their potential applications: a review. Crit Rev Biotechnol 2010, 30(1):41-62.

8. Oliveira C, Guimaraes PM, Domingues L: Recombinant microbial systems for improved beta-galactosidase production and biotechnological applications. Biotechnol Adv 2011, 29(6):600-609.

9. Chen W, Chen H, Xia Y, Zhao J, Tian F, Zhang H: Production, purification, and characterization of a potential thermostable galactosidase for milk lactose hydrolysis from Bacillus stearothermophilus. J Dairy Sci 2008, 91(5):1751-1758

10. Kengen SW, Luesink EJ, Stams AJ, Zehnder AJ: Purification and characterization of an extremely thermostable beta-glucosidase from the hyperthermophilic archaeon Pyrococcus furiosus. Eur J Biochem 1993, 213(1):305-312.

11. Park AR, Oh DK: Effects of galactose and glucose on the hydrolysis reaction of a thermostable beta-galactosidase from Caldicellulosiruptor saccharolyticus. Appl Microbiol Biotechnol 2010, 85(5):1427-1435.

12. Synowiecki J, Grzybowska B, Zdzieblo A: Sources, properties and suitability of new thermostable enzymes in food processing. Crit Rev Food Sci Nutr 2006, 46(3):197-205.

13. Smith JD, Robinson AS: Overexpression of an archaeal protein in yeast: secretion bottleneck at the ER. Biotechnol Bioeng 2002, 79(7):713-723.

14. Wang $X$, Sun $Y$, Ke F, Zhao H, Liu T, Xu L, Liu Y, Yan Y: Constitutive expression of Yarrowia lipolytica lipase LIP2 in Pichia pastoris using GAP as promoter. Appl Biochem Biotechnol 2012, 166(5):1355-1367.

15. Waterham HR, Digan ME, Koutz PJ, Lair SV, Cregg JM: Isolation of the Pichia pastoris glyceraldehyde-3-phosphate dehydrogenase gene and regulation and use of its promoter. Gene 1997, 186(1):37-44.

16. Zhang AL, Luo JX, Zhang TY, Pan YW, Tan YH, Fu CY, Tu FZ: Recent advances on the GAP promoter derived expression system of Pichia pastoris. Mol Biol Rep 2009, 36(6):1611-1619.

17. Zhang AL, Zhang TY, Luo JX, Chen SC, Guan WJ, Fu CY, Peng SQ, Li HL: Constitutive expression of human angiostatin in Pichia pastoris by highdensity cell culture. J Ind Microbiol Biotechnol 2007, 34(2):117-122.

18. Voorhorst WG, Eggen RI, Luesink EJ, De Vos WM: Characterization of the celB gene coding for beta-glucosidase from the hyperthermophilic archaeon Pyrococcus furiosus and its expression and site-directed mutation in Escherichia coli. J Bacterio/ 1995, 177(24):7105-7111.

19. Khatri NK, Gocke D, Trentmann O, Neubauer P, Hoffmann F: Single-chain antibody fragment production in Pichia pastoris: Benefits of prolonged pre-induction glycerol feeding. Biotechnol J 2011, 6(4):452-462

20. Padkina MV, Parfenova LV, Gradoboeva AE, Sambuk EV: Heterologous interferons synthesis in yeast Pichia pastoris]. Prikl Biokhim Mikrobiol 2010, 46(4):448-455

21. Pham TH, Quyen DT, Nghiem NM, Vu TD: Cloning, expression, purification, and properties of an endoglucanase gene (glycosyl hydrolase family 12) from Aspergillus niger VTCC-F021 in Pichia pastoris. J Microbiol Biotechnol 2011, 21(10):1012-1020.

22. Topakas E, Moukouli M, Dimarogona M, Vafiadi C, Christakopoulos P: Functional expression of a thermophilic glucuronyl esterase from Sporotrichum thermophile: identification of the nucleophilic serine. Appl Microbiol Biotechnol 2010, 87(5):1765-1772.

23. Zhang R, Fan Z, Kasuga T: Expression of cellobiose dehydrogenase from Neurospora crassa in Pichia pastoris and its purification and characterization. Protein Expr Purif 2011, 75(1):63-69.

24. Cieslinski H, Kur J, Bialkowska A, Baran I, Makowski K, Turkiewicz M: Cloning, expression, and purification of a recombinant cold-adapted betagalactosidase from antarctic bacterium Pseudoalteromonas sp. 22b. Protein Expr Purif 2005, 39(1):27-34.

25. Pan Q, Zhu J, Liu L, Cong Y, Hu F, Li J, Yu X: Functional identification of a putative beta-galactosidase gene in the special lac gene cluster of Lactobacillus acidophilus. Curr Microbiol 2010, 60(3):172-178.

26. Christakopoulos P, Goodenough PW, Kekos D, Macris BJ, Claeyssens M, Bhat MK: Purification and characterisation of an extracellular beta-glucosidase with transglycosylation and exo-glucosidase activities from Fusarium oxysporum. Eur J Biochem 1994, 224(2):379-385.

27. Karnchanatat A, Petsom A, Sangvanich P, Piaphukiew J, Whalley AJ, Reynolds CD, Sihanonth P: Purification and biochemical characterization of an extracellular beta-glucosidase from the wood-decaying fungus Daldinia eschscholzii (Ehrenb.:Fr.) Rehm. FEMS Microbiol Lett 2007, 270(1):162-170.

28. Riou C, Salmon JM, Vallier MJ, Gunata Z, Barre P: Purification, characterization, and substrate specificity of a novel highly glucosetolerant beta-glucosidase from Aspergillus oryzae. Appl Environ Microbiol 1998, 64(10):3607-3614.

29. Saha BC, Freer SN, Bothast RJ: Production, purification, and properties of a thermostable beta-glucosidase from a color variant strain of aureobasidium pullulans. Appl Environ Microbio/ 1994, 60(10):3774-3780.

30. Yoon JJ, Kim KY, Cha CJ: Purification and characterization of thermostable beta-glucosidase from the brown-rot basidiomycete Fomitopsis palustris grown on microcrystalline cellulose. J Microbiol 2008, 46(1):51-55.

doi:10.1186/1472-6750-13-73

Cite this article as: Li et al:: Preparation of lactose-free pasteurized milk with a recombinant thermostable $\beta$-glucosidase from Pyrococcus furiosus. BMC Biotechnology 2013 13:73.

\section{Submit your next manuscript to BioMed Central and take full advantage of:}

- Convenient online submission

- Thorough peer review

- No space constraints or color figure charges

- Immediate publication on acceptance

- Inclusion in PubMed, CAS, Scopus and Google Scholar

- Research which is freely available for redistribution 